\title{
Role of OCB and Demographic Factors in the Relationship of Motivation and Employee Performance
}

\author{
Tan Yew Huei ${ }^{1}$, Nur Naha Abu Mansor ${ }^{1}$, Huam Hon Tat ${ }^{2}$ \\ ${ }^{1}$ Faculty of Management, Universiti Teknologi Malaysia (Malaysia) \\ ${ }^{2}$ Faculty of Business, Quest International University Perak (Malaysia) \\ Yewhueitan87@hotmail.com,Nurnaha@utm.my,Dr.huam@gmail.com
}

Received June, 2013

Accepted April, 2014

\begin{abstract}
Purpose: This research seeks to broaden the study by investigating the interplay of organizational citizenship behaviour (OCB) and demographic factor (gender and organizational tenure) on the motivation and employee performance relationship.

Design/methodology/approach: Multiple linear regression was used to test the relationship between motivation (intrinsic and extrinsic) and employee performance among $(n=368)$ lecturers in Malaysia. To test the mediating effect of OCB, path analysis was employed. Furthermore, the demographic factors (gender and organizational tenure) was tested using the moderated multiple regression analysis.

Findings: Significant differences in explaining the variance of employee performance was found between intrinsic motivation and extrinsic motivation. In addition, OCB was found perfectly mediating the relationship of extrinsic motivation and employee performance, however, OCB was found partially mediating the relationship between intrinsic motivation and employee performance. Furthermore, gender and organizational tenure do not show any moderate results in the relationship between OCB and employee performance.
\end{abstract}


Research limitations/implications: Study limitations (e.g. cross-sectional research design and biasness) and future opportunities are outlined.

Practical implications: Argues that the suitable type of motivation in explaining the variances of employee performance. Also, identifies the important of OCB between the motivation and employee performance relationship, thus gender and organizational tenure were not significant to OCB and employee performance relationship.

Social implications: HR can help an organization to succeed, provided that the suitable motivations are adopted to monitor lecturer performance and helping behavior. In addition, HR should not emphasize too much of gender and organizational tenure to justify the lecturer performance as the findings show insignificant relationship.

Originality/value: This paper identifies and discusses the types of motivation that explain higher variance of employee performance and how OCB play role as mediator in the motivation and employee performance relationship. In addition, the moderating effect of gender and organizational tenure were also discussed. This is the first attempt to include all the variables in the same theoretical framework.

Keywords: Intrinsic motivation, extrinsic motivation, $O C B$, employee performance, gender and organizational tenure

Jel Codes: M10, M14, L15

\section{Introduction}

Motivation has been given the credit of bringing success to the employee performance. However, not many empirical discussions could be found within the higher education industry, especially among lecturers. Indeed, Malaysia believes that education is one of the critical elements in the development of the country (Arokiasamy, Ismail, Ahmad \& Othman, 2009). Education among individuals is a means to career term and social mobility, whereas from the government's perspective, it is a crucial step in the country's economic development (Benjamin, Marathamuthu, Muthaiayh \& Raman, 2011). The crucial workforce in the universities themselves, are lecturers (Arokiasamy et al., 2009).

Over the past decades, intrinsic motivation has been widely studied (Ryan \& Deci, 2000). Some research defined this nexus between human and tasks exist because of satisfaction and fulfilment a person's experience after completing a desire task (Ryan \& Deci, 2000). This satisfaction and fulfilment were proven to be the driving forces of intrinsic motivation that input inside all individuals. Meanwhile, another type of motivation that share opposite value of 
intrinsic motivation was named as extrinsic motivation. Extrinsic motivation was defined as individual willingness to complete a task because of some separable outcomes or rewards (Ryan \& Deci, 2000). Even though, most researchers agree that intrinsic motivation plays a prominent role among individuals, some of the job tasks and social demands that are not willing to be accomplished by individual have decreased the freedom to be intrinsically motivated (Ryan \& Deci, 2000). According to Ryan and Deci (2000), many educational activities implemented in the education industry are not designed to be interesting. As a result, the challenge faced by the industry is about how to motivate lecturers to be self-regulated with such activities, in the absence of external pressure and able to carry out the activities on their own.

Furthermore, when OCB was first introduced in early 1930 s by Barnard (1938), researchers started to develop a proper dimension to identify the OCB. The first two dimensions were introduced by Smith, Organ and Near (1983), which only consisted of altruism and generalized compliance. This two dimension were used to enhance the company effectiveness and efficiency in different ways (Smith et al., 1983). However, all dimensions introduced by the previous researchers were not accepted widely until the new dimension which introduced by Organ (1988) was found. According to Organ (1988), OCB dimension should consist of altruism, courtesy, sportsmanship, civic virtue and conscientiousness.

\section{Literature Review}

\subsection{Theoretical Background}

The present model was developed according to the theoretical and empirical studies from the psychology and human management literature, particularly on the work of the following researchers: Ryan and Deci (2000), Organ (1988), Ishak, Suhaida and Yuzainee (2009), Megginson and Whitaker (2003) and Meyer, Allen and Smith (1993).

The key theoretical linkage in this study is the lecturer's OCB is affected by intrinsic and extrinsic motivation, which in return it affects their performance. To explain the existence of intrinsic and extrinsic motivation-OCB relationship, the Social Exchange Theory (SET) by Blau (1964) is used as a basis. Social exchange theory (SET) explained that all human behaviour involves benefit maximization and cost minimization. Based on SET posit that one-time exchange can relatively turn to long-term relationship of interest (Molm, 1997). Therefore, the contribution of knowledge of employee can be affected by the cost and benefit. For example, the cost of helping the institutions or colleagues are time, effort and loss of knowledge power; however, the benefits gained include enjoyment in helping others, organization rewards and 
knowledge self-efficacy (Kankanhalli, Tan \& Kwok-Kee, 2005). Therefore, it involves both intrinsic and extrinsic benefits (Deci and Ryan, 1980; Vallerand, 1997). For example, lecturers who enjoy helping institutions or colleagues perform OCB because they are intrinsically motivated. However, lecturers who are willing to perform extra in exchange of rewards, they are extrinsically motivated.

To explain the existence of OCB-employee performance relationship, the norm of reciprocity theory (Gouldner, 1960) and SET were used as a basis. This theory establishes the obligation to return a favour and therefore, sustains relationships. It states that people should help those who have helped them and people should not injure those who have helped them (Gouldner, 1960). According to Rook (1987), the universal norm of reciprocity is the strongest of the social norms relevant to helping behaviour. By reciprocating good deeds, the individual will increase the chances of receiving benefits in the future (Gouldner, 1960). In the educational settings, employees of higher educational institutions sometimes may perform extra-role behaviors, which add value to the institutions.

Gender roles create expectations of the behaviors necessary to fulfill the role of 'female' and 'male'. In other words, people are expected to behave in ways consistent with their socially prescribed gender roles. Past studies (e.g: Deluga, 1998; Morrison, 1994; Van Dyne \& Ang, 1998) have generally reported differences between males and females in terms of their OCB enactment. The five dimensions of OCB encompass behavioral expectations that appear consistent with masculine and feminine stereotypes and role expectations. In this light, Kidder and Parks (2001) categorized OCB into two groups. Altruism, courtesy and conscientiousness are considered feminine OCBs, whereas sportsmanship and civic-virtue are perceived as masculine OCBs.

Meanwhile, human capital theory (Becker, 1964) suggested that long-tenured workers are better performers because they have accumulated more job-related knowledge over the course of their careers. Individuals can accumulate human capital through both formal education and work experience (Meyer, Griffith \& Daugherty, 2004; Singer \& Bruhns, 1991; Strober, 1990). Economists suggest that experience and education are signals to organizations about employees' knowledge and skill levels (Sicherman \& Galor, 1990). The labour market rewards individuals from acquiring more human capital with access to better jobs, higher earnings, and greater incentives to remain (Strober, 1990). In turn, employees with longer tenure have greater incentives to perform well into the future.

Generally, the justification for the choice of these models and theories lies in their explicit theoretical relevance in gaining a complete perspective of lecturer motivation that might influence their $O C B$, and subsequently affect their performance. The initial emphasis of this 
study was on the comparison of the two motivation dimensions, namely intrinsic motivation and extrinsic motivation. These dimensions were deemed to be significant with lecturer's OCB. Besides, this study also looked at OCB and its relationship with employee performance. However, the OCB-employee performance relationships were expected to be contingent upon one factor. One of the particular interest in this study was the demographic factors variable.

\subsection{Motivation and Employee Performance}

In studies on motivation for teaching, it is common to distinguish between intrinsic and extrinsic reasons for choosing the profession (Roness, 2011; Eyal \& Roth, 2011; Moran Kilpatrick, Abbott, Dallat \& Mcclune, 2001). Intrinsically motivated lecturers are focused on the activity that is significantly related to their inherent satisfaction or joy (Ryan \& Deci, 2009). Meanwhile, rewards and benefits are the driven forces for the lecturers who are extrinsically motivated (Ryan \& Deci, 2009). Brookhart and Freeman (1992) reviewed American research that has sought to determine the characteristics of incoming academic candidates and they find that the reasons for choosing teaching were connected to intrinsic sources of motivation. Studies in Australia indicate that personal fulfilment, the desire to work with young children and to make a difference in their life and the opportunity to experience a meaningful engagement with the subject of their choice are intrinsic motivational factors (Manuel \& Brindley, 2005; Manuel \& Hughes, 2006).

Meantime, extrinsic motivation was found to be significant to employee performance (Stringer, Didham \& Theivananthampillai, 2011; Manolopoulos, 2008; Decoene \& Bruggeman, 2006). The public sector is more likely to engage in extrinsic motivation rather than intrinsic motivation and this extrinsic motivation was related to better organizational outcomes (Manolopoulos, 2008). Tough, overemphasizing on the use of extrinsic motivation could lead to negative effects (Kelsey, 2010). Extrinsically motivated adaptor may exert minimal effort to perform a task and may stop an activity when reinforcement discontinues and decrease the performance (Cheng \& Yeh, 2009). In addition, it is hard to determine which motivational factors influence the intensity and quality of the production of intangible firm-specific pool resources, especially tacit knowledge (Osterloh Frost \& Frey, 2002). Therefore, it could be a serious limitation since not only the introduction of the distinction but also the interplay between intrinsic motivation and extrinsic motivation and also with other factors. In order to keep the educators in the profession, it is important to build up a better understanding of what teachers actually say about their motivation (Roness, 2011). Therefore, it is important to identify which type of motivation the lectures are likely to engage with in order to improve their performance. 
Therefore, this research hypothesizes that:

- H1: Intrinsic motivation is better in terms of explaining the variances of employee performance among lecturers in Malaysia.

- H2: Extrinsic motivation is better in terms of explaining the variances of employee performance among lecturers in Malaysia.

\subsection{Intrinsic Motivation, Extrinsic Motivation and Employee Performance: OCB as Mediator}

OCB comprises extra-role behaviours that are not within role but nevertheless of great importance for efficient processes in organizations (Organ, 1988; Podsakoff, Ahearne \& Mackenzie, 1997). Building upon work (Ehrhart, Bliese \& Thomas, 2006) that supports OCB as a means of positively influencing organizational performance; it is argued that the OCB of the implementation team should result in a successful outcome. Niehoff (2005) suggested that OCB exerts positive influence on organizational performance because it provides socioemotional support to other employees, and facilitates the work of others. Therefore, employees may contribute to organizational effectiveness by building socio-emotional support in the organization and facilitating more efficient work behaviour.

Helping behaviour stimulates performance because new colleagues are easily integrated into the group. Therefore, the group can establish best practices, ease in coordination, and thus variations of performance become less probable (Boerner, Eisenbeiss \& Griesser, 2007). Given high levels of sportsmanship, the group does not need to spend much energy and time on group maintenance functions. Hence, sportsmanship may raise the attractiveness of group membership for high performers (Boerner et al., 2007). With increasing of followers' conscientiousness, leaders may tend to empower their followers and thus, raise their performance motivation. Accordingly, in a comprehensive literature review, Podsakoff, Mackenzie, Paine and Bachrach (2000) found OCB to predict followers' performance.

OCB is vital for productivity but organizations fail to forecast the entire spectrum of subordinate behaviours needed for achieving goals through stated job descriptions (Organ 1988; Deluga, 1994). A researcher (Organ, 1990) suggested that OCBs play an important role in the development of social capital in organizations. Their conceptual framework identified that OCBs include altruism, sportsmanship, civic virtue, courtesy and conscientiousness, which contribute to the creation of structural, relational and cognitive aspects of social capital (Bolino, Turnley \& Bloodgood, 2002). 
As suggested, salient identification enhances the frequency of cooperation and cooperative behaviours (Islam, Anwar, Khan, Rasli, Ungku Ahmad \& Ahmed, 2012). When individuals are identified by their organizations, they are more willing to engage in cooperative, altruistic and spontaneous unrewarded citizenship behaviour (Islam et al., 2012). Briefly, OCB may mediate the relationship between motivation and employee performance among lecturers in Malaysian higher education.

- H3a: The effect of OCB is perfectly mediating the relationship between intrinsic motivation and employee performance among lecturers in Malaysia higher education.

- H3b: The effect of OCB is perfectly mediating the relationship between extrinsic motivation and employee performance among lecturers in Malaysia higher education.

\subsection{OCB and Employee Performance: Gender and Organization Tenure as Moderator}

The notion of 'role' is of central importance in understanding the moderating effect of gender on the relationship between OCB and employee performance. Gender roles create expectations of the behaviours necessary to fulfil the role of 'female' and 'male'. In other words, people are expected to behave in ways that are consistent with their socially prescribed gender roles. Several past studies (Deluga, 1998; Morrison, 1994; Van Dyne \& Ang, 1998) have generally reported differences between males and females in terms of their OCB enactment. The five dimensions of OCB encompass behavioural expectations that appear consistent with masculine and feminine stereotypes and role expectations. In this light, Kidder and Parks (2001) categorized OCB into two groups. Altruism, courtesy and conscientiousness are considered feminine OCBs, whereas sportsmanship and civic-virtue are perceived as masculine OCBs.

With regard to altruism, Kidder and Parks (2001) further argue that while it would be inaccurate to suggest that males do not help others, females are expected to be more nurturing and caring (Eagly \& Crowly, 1986; Erdle, Sansom, Cole \& Heapy, 1992) and indeed past research (e.g. George, Carroll, Kersnick \& Calderon, 1998; Morrison, 1994; Van Dyne \& Ang, 1998) has found that females are perceived to be more altruistic and helpful than males. Additionally, asking for help violates masculine gender role norms (Good, Dell \& Mintz, 1989). Similarly, courtesy fits feminine stereotypes, where females are seen as more aware of other's feelings and needs. Again, conscientious behaviours that include doing the job well with meticulous attention to detail (Organ, 1988) appear to be consistent with feminine stereotypes and role-expectations. On the contrary, sportsmanship and civic virtue have expected more from males than females. 
Given the above, if people are expected to perform the OCBs related to their gender roles, this would suggest that females would get more credit, in terms of rewards or academic success than males for performing masculine OCBs, for instance, civic virtue and sportsmanship. Implicitly, the behaviours of the females go beyond expectations, and thus are likely to be rewarded. This would also be true for males performing feminine OCBs such as altruism, courtesy and conscientiousness. Therefore, this research hypothesizes that:

- H4a: The effects of gender moderate the relationship between OCB and employee performance among lecturers in Malaysia higher education.

In addition, according to $\mathrm{Ng}$ and Feldman (2010), much less theoretical and empirical work has been conducted on how long organizational tenure affects performance. This gap in the literature is due to the widespread assumption that workers with more years of service are generally better performers (McEnrue, 1988). The researchers have long argued that employees with more years of service know how to perform their jobs better (Wagner, Ferris, Fandt \& Wayne, 1987), whereas poor-performing employees are likely to be weeded out before they accumulate many years of service (Schneider, Goldstein \& Smith, 1995).

Cohen (1997) postulated that since employees accumulate relevant work experience as tenure increases, both their autonomy and their performance also grow. Sturman (2003) also argued that the explicit and tacit organizational knowledge gained through organizational tenure have unique positive effects on job performance. Moreover, given that increases in organizational tenure are also accompanied by increases in chronological age, the types of performance that long-tenured employees enjoy and excel at might be different from those of young new hires. For instance, research on aging and development suggests that older individuals adapt to aging by giving higher priority to socially oriented tasks that are emotionally satisfying to them (Carstensen, Issacowitz \& Charles, 1999) and that they will invest their resources more in those goals that match their motivations and interests (Beier \& Ackerman, 2001). As such, longer tenured employees may dedicate more resources to social-oriented tasks (helping others, making constructive suggestions) than other technically oriented job tasks. Therefore, this research hypothesizes that:

- H4b: The effects of organizational tenure moderate the relationship between OCB and employee performance among lecturers in Malaysia higher education.

As depicted in Figure 1, the current study proposes that OCB mediates the relationship between motivation and employee performance as well as gender and organization tenure moderate the OCB-employee performance relationship. Meantime, investigation on the motivation effects on employee performance also shown in Figure 1. 


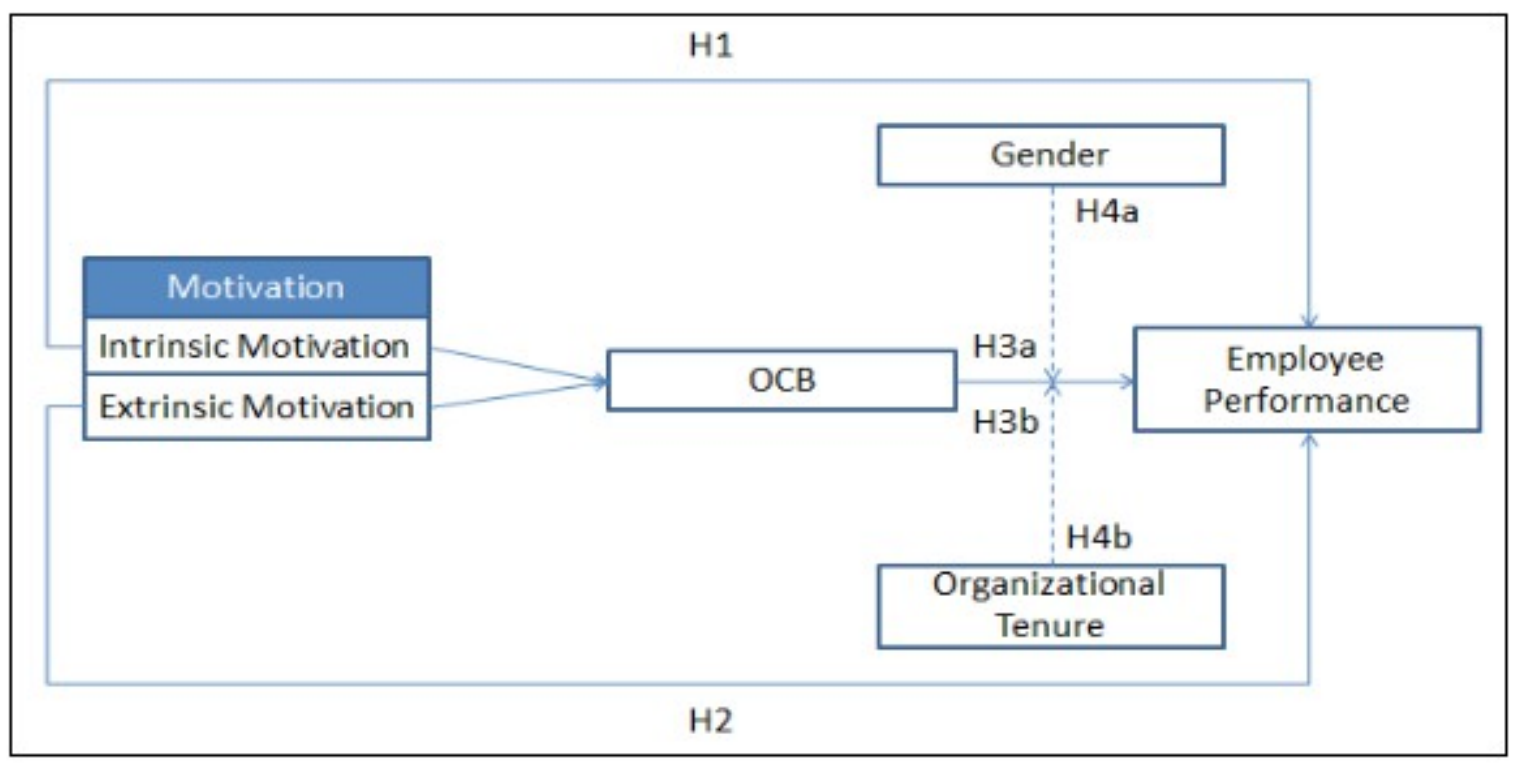

Figure 1. Research Framework

\section{Methodology}

\subsection{Participant}

With 6,000 questionnaires sent out through electronic mail to the five major research universities in Malaysia, 368 lecturers participated. The participants were aged between $36-$ 45 years old (frequency $=156,42.4 \%$ ). In addition, the gender of participants were found to be almost equal (Male: frequency $=181,49.2 \%$; Female: frequency $=187,50.8 \%$ ) and most of the participants are Malay participants (frequency $=266,72.3 \%$ ). Out of the 368 participants, most of them obtain a Postgraduate Degree (frequency $=251,68.2 \%$ ). In addition, it is not surprising that out of 368 participants, 302 of them were married (frequency $=302,82.1 \%$ ) and the mean age of the participants was between $36-45$ years old and most of the participants are Malaysian (frequency $=346,94 \%$ ). As expected, it is also not a surprise that most of the participants have a long working experience in academic industry (frequency $=290,78.8 \%$ ) because based on the mean score, most of them select more than 6 years of working experience in academic industry and most of them are senior lecturers (frequency $=152,41.3 \%$ ). Furthermore, most of the participants spend more than 6 years working in the same organization (frequency $=246,66.8 \%$ ). Lastly, participants who return the questionnaires are slightly more from science area (frequency $=205,55.7 \%$ ) and the remaining are those from social science area (frequency $=163,44.3 \%$ ). 


\subsection{Measurement}

This study adopts split-half reliability and inter-item because it examines the degree of how unified the items are in the instruments and the consistency of respondents' answer for all items (Herzog, 1996). Alpha Cronbach's coefficient alpha and spearman brown coefficient were used because they provide a measure of the degree to which the full scale, derived from a set of items, is free from error (Cozby, 2005). The questionnaire is considered highly reliable when the coefficient value $(\alpha)$ is above 0.70 as suggested by Hair, Anderson, Tatham and Black (1998). In conclusion, the items in this study were considered reliable when the alpha Cronbach and coefficient value was above 0.70 .

Multiple regression analysis is used for predicting the unknown value of a variable from the known value of two or more variables-also called the predictors (Hair et al., 1998). The strength of the relationship stipulated by the regression equation can be determined by using the appropriate measures of association. In multiple regressions, the strength of association is measured by the square of the multiple correlation coefficients, $R^{2}$, which is called the coefficient of multiple determinations. It measures the strength of the relationship between the dependent variable and independent variables. In this study, the larger the $\mathrm{R}^{2}$ is, the more significantly the brand equity is associated with customer loyalty.

The moderating effect of gender and organizational tenure was analyzed using moderated multiple regression (MMR) analysis. To determine the presence of moderating effect, the OLS model was then compared with the MMR model which was represented by Equation 2. Below are the definitions of the equation:

$$
\begin{aligned}
& \text { Equation (1) } Y=i_{1}+b_{1} X+c_{1} Z+e_{1} \\
& \text { Equation (2) } Y=i_{2}+b_{2} X+c_{2} Z+d_{2}\left(X^{*} Z\right)+e_{2} \\
& \text { Where: } \quad Y=\text { dependent variable; } \\
& \mathrm{X}=\text { independent variable; } \\
& Z=\text { moderator } \\
& X * Z=\text { the multiplier of independent variable and moderator } \\
& i=\text { constant value for independent variable } \\
& \text { b, c } d=\text { coefficients for independent variable and moderator } \\
& \mathrm{e}=\text { regression residual }
\end{aligned}
$$


$\mathrm{R}^{2}$ value is observed to determine the significant effect of moderator to the studied relationship. If changes in $R^{2}\left(\Delta R^{2}\right)$ are statistical for the equations, then a significant moderation effect is present (Hair et al., 1998). Dummy variable was created for gender and organizational tenure in this study, which was introduced into a regression equation (Hair, Anderson, Tatham \& Black, 2009).

\section{Findings}

\subsection{Hypotheses Testing}

Table 1 demonstrates the mean, standard deviation, reliability and correlation between the variables. Based on the results, there was a significant relationship between all the variables. All variables reported significant at $p<0.01$, and showed reliability at 0.7 .

\begin{tabular}{|l|c|c|c|c|c|c|}
\hline Variables & M & SD & $\mathbf{1}$ & $\mathbf{2}$ & $\mathbf{3}$ & $\mathbf{4}$ \\
\hline Intrinsic motivation & 83.60 & 10.08 & $(0.899)$ & & & \\
\hline Extrinsic motivation & 70.26 & 10.00 & $0.356^{* *}$ & $(0.731)$ & & \\
\hline OCB & 72.69 & 10.47 & $0.571^{* *}$ & $0.459^{* *}$ & $(0.896)$ & \\
\hline $\begin{array}{l}\text { Employee } \\
\text { Performance }\end{array}$ & 98.95 & 13.11 & $0.585^{* *}$ & $0.307^{* *}$ & $0.732^{* *}$ & $(0.850)$ \\
\hline
\end{tabular}

Table 1. Mean standard deviation, reliability and correlation

Table 2 and 3 represents the multiple regression analysis between intrinsic motivation and employee performance as well as extrinsic motivation and employee performance. Table 2 shows that the intrinsic motivation dimensions were positively and significantly associated with employee performance. As seen from the coefficient of determination, adjusted $\mathrm{R}^{2}$, intrinsic motivation dimensions accounted for $34.1 \%$ of the variance in employee performance and, all four dimension dimensions (meaningfulness: $\beta=.469, p<.01$; choice: $\beta=.485, p<.01$; competence: $\beta=0.566, p<.01$; progress: $\beta=0.532, p<.01$ ).

The value of adjusted $\mathrm{R}^{2}$ in Table 3 implies that the extrinsic motivation dimensions explained $9.2 \%$ of the total variance in employee performance and extrinsic motivation dimensions were positively associated with employee performance. Identified regulation and integrated regulation were the only dimensions significantly associated with employee performance (identified regulation: $\beta=.485, p<.01$; integrated regulation: $\beta=.575, p<.01$ ). 
Besides, the adjusted $\mathrm{R}^{2}$ values from both regressions were used to test the predictive validity. In terms of adjusted $\mathrm{R}^{2}$ intrinsic motivation model had a much higher value $(34.1 \%$ versus $9.2 \%$ ) compared to the extrinsic motivation dimensions in terms of its predictive validity. The intrinsic motivation, therefore, has higher predictive validity than extrinsic motivation dimensions. This suggests that intrinsic motivation dimensions have a higher ability to differentiate among lecturers in response to employee performance. All these results provided grounds for full support of hypothesis $\mathrm{H} 1$, which says that the intrinsic motivation is better in terms of explaining the variances of employee performance among lecturers in Malaysia. However, the hypothesis $\mathrm{H} 2$ was rejected.

\begin{tabular}{|l|c|c|}
\hline \multirow{2}{*}{ Intrinsic Motivation } & \multicolumn{2}{|c|}{ Employee Performance } \\
\cline { 2 - 3 } & Beta $(\boldsymbol{\beta})$ & Sig. \\
\hline Meaningfulness & 0.469 & 0.000 \\
\hline Choice & 0.485 & 0.000 \\
\hline Competence & 0.566 & 0.000 \\
\hline Progress & 0.532 & 0.000 \\
\hline $\mathbf{R}^{2}$ & 0.342 & \\
\hline Adjusted $\mathbf{R}^{\mathbf{2}}$ & 0.341 & \\
\hline F-value & $190.483^{* *}$ & \multicolumn{2}{|c}{} \\
\cline { 1 - 2 } & \multicolumn{2}{|c|}{} \\
\hline
\end{tabular}

Note: $* * p<0.01$

Table 2. Results of multiple regression analysis between intrinsic motivation and employee performance

\begin{tabular}{|l|c|c|}
\hline \multirow{2}{*}{ Extrinsic Motivation } & \multicolumn{2}{|c|}{ Employee Performance } \\
\cline { 2 - 3 } & Beta $(\boldsymbol{\beta})$ & Sig. \\
\hline External Regulation & 0.54 & 0.305 \\
\hline Introjected Regulation & -0.051 & 0.329 \\
\hline Identified Regulation & 0.485 & 0.000 \\
\hline Integrated Regulation & 0.575 & 0.000 \\
\hline $\mathbf{R}^{2}$ & 0.094 & \\
\hline Adjusted $\mathbf{R}^{\mathbf{2}}$ & 0.092 & \\
\hline F-value & $38.184^{* *}$ & \\
\hline Note: $* * \mathrm{p}<0.01$ & & \\
\hline
\end{tabular}

Table 3. Results of multiple regressions analysis between extrinsic motivation and employee performance

Table 4 demonstrates the summarized findings of the three equations. In the first equation, intrinsic motivation demonstrates the significant effect on employee performance $(\beta=0.585$, $p<0.05)$. In addition, intrinsic motivation also found to significantly affect the OCB $(\beta=0.571$, $p<0.05)$. In the third equation, the finding showed that OCB significantly affects employee performance $(\beta=0.590, p<0.05)$ while intrinsic motivation still remains significant effect with employee performance $(\beta=0.248, p<0.05)$. Therefore, it can be concluded that there was no 
perfect mediation was found on the effect of OCB. Therefore, the null hypothesis was rejected.

Meantime, Table 5 demonstrates the summarized findings of the three equations. In the first equation, extrinsic motivation demonstrates the significant effect on employee performance ( $\beta$ $=0.307, p<0.05)$. In addition, extrinsic motivation also found to significantly affect the OCB $(\beta=0.459, p<0.05)$. In the third equation, the finding showed that OCB significantly affects employee performance $(\beta=0.748, p<0.05)$. However, extrinsic motivation showed no significant effect with employee performance $(\beta=-0.036, p<0.05)$. Therefore, it can be concluded that there was a perfect mediation relationship was found on the effect of OCB. Therefore, the null hypothesis was supported.

\begin{tabular}{|c|c|c|c|c|c|c|}
\hline \multirow{2}{*}{ Variables } & \multicolumn{2}{|c|}{ Equation 1 } & \multicolumn{2}{c|}{ Equation 2 } & \multicolumn{2}{c|}{ Equation 3 } \\
\cline { 2 - 7 } & $\boldsymbol{\beta}$ & $\boldsymbol{t}$ & $\boldsymbol{\beta}$ & $\boldsymbol{t}$ & $\boldsymbol{\beta}$ & $\boldsymbol{t}$ \\
\hline Intrinsic Motivation & $0.585^{* *}$ & 13.802 & $0.571^{* *}$ & 13.313 & $0.248^{* *}$ & 5.982 \\
\hline OCB & \multicolumn{4}{|r}{} & $0.590^{* *}$ & 14.213 \\
\cline { 5 - 7 }
\end{tabular}

Note: $* * p<0.05, \beta=$ Standardized Beta Coefficient

Table 4. The Mediating Effect of OCB on the Relationship of Intrinsic Motivation and Employee Performance

\begin{tabular}{|c|c|c|c|c|c|c|}
\hline \multirow{2}{*}{ Variables } & \multicolumn{2}{|c|}{ Equation1 } & \multicolumn{2}{c|}{ Equation 2 } & \multicolumn{2}{c|}{ Equation 3 } \\
\cline { 2 - 7 } & $\boldsymbol{\beta}$ & $\boldsymbol{t}$ & $\boldsymbol{\beta}$ & $\boldsymbol{t}$ & $\boldsymbol{\beta}$ & $\boldsymbol{t}$ \\
\hline Extrinsic Motivation & $0.307 * *$ & 6.179 & $0.459 * *$ & 9.787 & -0.036 & -0.892 \\
\hline OCB & \multicolumn{4}{|r}{} & $0.748 * *$ & 18.641 \\
\cline { 5 - 7 }
\end{tabular}

Note: ${ }^{* *} p<0.05, \beta=$ Standardized Beta Coefficient

Table 5. The Mediating Effect of OCB on the Relationship of Extrinsic Motivation and Employee Performance

Results of moderated multiple regressions analysis for Model 1 are shown as in Table 6, $\mathrm{R}=.732^{\mathrm{a}}, \mathrm{R}^{2}=.535$ and $\mathrm{F}$ change $=421.273, p<0.001$. This $\mathrm{R}^{2}$ means that $53.5 \%$ of the variance in job performance is explained by OCB and gender groups. Model 2 shows the results after the product term (OCB*gender) was included in the equation. As indicated in Table 6, the addition of the product term resulted in an $\mathrm{R}^{2}$ change of .004 and $\mathrm{F}$ change $=3.357, p>$ 0.05]. The results do not support for the presence of a moderating effect. The results summarized that the relationship between OCB and employee performance was not moderated by gender. The sig. $\mathrm{F}$ change values in the table also suggest that gender was a homologizer. It is a type of moderator that does not interact with the predictor, and it is not significantly related to either the predictor or criterion variable (Sharma, Durand \& Gur-Arie, 1981). Therefore, H4a was not supported. 
In addition, results of moderated multiple regression analysis for Model 1 are shown as in Table $7, R=.732^{\mathrm{a}}, \mathrm{R}^{2}=.535$ and $\mathrm{F}$ change $\left.=421.273, \mathrm{p}<0.001\right]$. This $\mathrm{R}^{2}$ means that $53.5 \%$ of the variance in job performance is explained by OCB and organizational tenure group. Model 2 shows the results after the product term (OCB*organizational tenure) was included in the equation. As indicated in Table 7, there is no changes in $\mathrm{R}^{2}$ and $\mathrm{F}$ change $=0.012, p>0.05$. The results do not support the presence of a moderating effect. Therefore, $\mathrm{H} 4 \mathrm{~b}$ was rejected.

\begin{tabular}{|c|c|c|c|c|c|c|c|}
\hline \multirow{2}{*}{ Model } & \multirow{2}{*}{$\mathbf{R}$} & \multirow{2}{*}{$\mathbf{R}^{\mathbf{2}}$} & $\begin{array}{c}\text { Adjusted } \\
\mathbf{R}^{\mathbf{2}}\end{array}$ & \multirow{2}{*}{ Std. Error } & \multicolumn{3}{|c|}{ Change statistics } \\
\cline { 5 - 8 } & & & & $\mathbf{\Delta R}^{\mathbf{2}}$ & F change & Sig. F change \\
\hline $\mathbf{1}$ & $.732^{\mathrm{a}}$ & .535 & .534 & 8.95 & .353 & 421.273 & 0.000 \\
\hline $\mathbf{2}$ & $.734^{\mathrm{b}}$ & .539 & .537 & 8.92 & .004 & 3.357 & 0.068 \\
\hline
\end{tabular}

Note: $\mathrm{a}=$ Predictor: (constant), OCB; $\mathrm{b}=$ Predictor: (constant), OCB, Dummy variable gender

Table 6. The Moderating Effect of Gender on the Relationship of OCB and Employee Performance

\begin{tabular}{|c|c|c|c|c|c|c|c|}
\hline \multirow{2}{*}{ Model } & \multirow{2}{*}{$\mathbf{R}$} & \multirow{2}{*}{$\mathbf{R}^{2}$} & \multirow{2}{*}{$\begin{array}{c}\text { Adjusted } \\
\mathbf{R}^{2}\end{array}$} & \multirow{2}{*}{ Std. Error } & \multicolumn{3}{|c|}{ Change statistics } \\
\hline & & & & & $\Delta \mathbf{R}^{2}$ & F change & Sig. F change \\
\hline 1 & $.732^{\mathrm{a}}$ & .535 & .534 & 8.95 & .535 & 421.273 & 0.000 \\
\hline 2 & $.732^{\mathrm{b}}$ & .535 & .533 & 8.96 & .000 & 0.012 & 0.913 \\
\hline
\end{tabular}

Table 7. The Moderating Effect of Organizational Tenure on the Relationship of OCB and Employee Performance

\section{Discussion}

The purpose of this study was to explore the variance between intrinsic motivation and extrinsic motivation in relationship to employee performance. In addition, this study also investigates the mediating effect of $O C B$ and the moderating effect on gender and organization tenure. Specifically, substantial evidence based on previous empirical work support the relationship between motivation and employee performance; however, limited amount of evidence point to a link comparing the variances of motivation in explaining the employee performance. In addition, smaller amount of evidence based on more recent studies has begun to investigate the mediating effect of OCB; however, these streams of work have largely concentrate to industry other than higher learning, specifically lecturers. Moreover, past studies (e.g. Deluga, 1998; Morrison, 1994; Van Dyne \& Ang, 1998) have generally reported differences between males and females in terms of their OCB enactment and organization tenure also reported have unique positive effects on job performance (Sturman, 2003). Therefore, gender difference and organizational tenure may affect the OCB-employee performance relationship. As such, an examination of the suitable types of motivation is used 
in determining the employee performance, interplay of $\mathrm{OCB}$, gender and organization tenure represented an important need in the human resource management literature, and thus, a key contribution of the present study.

In general, our findings only support two of our predictions: Intrinsic motivation explain higher variance in explaining the lecturer's performance, OCB mediate the relationship between extrinsic motivation and employee performance. On the contrary to our predictions, extrinsic motivation explaining lower variances compare to employee performance, OCB does not mediate the relationship between intrinsic motivation and extrinsic motivation, gender and organizational tenure does not moderate the OCB-employee performance relationship.

\section{Theoretical and practical implication}

The findings on Pearson correlation analysis have confirmed that there is a significant relationship between intrinsic motivation and extrinsic motivation on employee performance. Then, further analysis is conducted using multiple regression analysis, which has also highlighted that intrinsic motivation and extrinsic motivation significantly improve the employee performance. Both findings, therefore, propose that intrinsic motivation and extrinsic motivation are imperative in developing and promoting higher performance among lecturers. Both motivations are also responsible for encouraging employee to positively respond to his/her performance. In other words, both motivations have become a predominant issue to influence employee performance.

The current findings thus enhance the understanding of significance of intrinsic motivation and extrinsic motivation on employee performance by suggesting the OCB as the mediating factor. As highlighted in aforementioned earlier, little is known about the mediating effect of OCB on the relationship between motivation and employee performance. This study has discovered that $O C B$ does not perfectly mediate the relationship between intrinsic motivation and employee performance. However, it does decrease the relationship between intrinsic motivation and employee performance. Meanwhile, the findings showed that OCB is perfectly mediated the relationship between extrinsic motivation and employee performance. The evidence denotes that it is important to practice the value of OCB among lecturers who are extrinsically motivated to increase their performance.

On top of that, the findings of this study will enrich employee performance literature, particularly on ways in which the relationship between OCB and employee performance does not moderate by gender and organizational tenure. It is believed that the employee performance has not been controlled by gender and organizational tenure among lecturers. It 
is also believed that the masculine and feminine stereotype effect does not imply in higher learning, especially among lecturers. Studies from other industries have demonstrated that organizational tenure and gender are the most common moderators. However, it is interesting to find out that both moderators do not have any impact on lecturers. It can be concluded that the nature of job and industry holds strong significance in causing the result that varies among different industries.

Based on the findings and conclusion of this study, several important practical contributions pertaining to the effect of employee performance were identified.

- First, the Ministry of Higher Education should employ the potential lecturers who understand the value of being a lecturer. Special attention should be provided to those lecturers who have a positive behaviour towards their job and tend to enjoy the job as a lecturer. This is because the teachers must be interested in what they teach and in the children when they are teaching. If they are not interested in the work at all, they can never motivate the class to learn.

- Second, the organization should not employ too much of regulations to monitor the lecturers' activities or promote the lecturers ego attainment whenever they accomplished something. Based on the findings, it can be stated that more regulations, punishments, and ego attainment tend to decrease the lecturers' performance. Therefore, the organizations should give more freedom to the lecturers and help them to attain certain skill or knowledge that the lecturers can treat as their own.

- Third, the organization should focus more to promote the lecturer's prosocial behaviour. Based on the finding, it is demonstrated that the lecturers who are extrinsically motivated are monitored by their sense of helping behaviour whenever they perform a task. Therefore, the organizations should encourage the lecturers to participate or carry out some activities in a group. This could increase the interaction with other lecturers which could promote their helping behaviour indirectly.

- Four, the lecturer's sense of helping behaviour towards better performance was not monitored either with gender or organizational tenure. Therefore, choosing the suitable lecturers for promotion should not account the duration they work with the organizations or be gender specific because it does not show greater performance for those who work longer or different in gender. 


\section{Limitations and recommendations for future study}

As with most research, the results of this study should be interpreted with consideration of several limitations. First, the cross-sectional nature of the study does not guarantee accurate results. Individual who is born in difference period of time may share different experience and behaviour. Therefore, we are not able to claim an accurate causal relationship based on this results. Future research would be recommended by using a longitudinal design to test the present findings.

Second, the study relied on employee self-reports of employee performance. Due to the reason that lecturers was believe to be a professional group members, organizations do not monitor closely on each lecturer individually. Therefore, we could not obtain departmental or managerial reports on the lecturer's performance and behaviour. As a result, we could not deny the fact that there would be biasness in answering the questionnaires. Based on this reason, we suggest that future research should impose controllable determinants over employee performance and OCB.

Finally, the findings of the study were not entirely representative to other industry. This study was only applicable to the higher learning industry because the employee performance measurement employed was set to investigate the lecturer's performance rather than other job performance.

\section{Conclusion}

Overall, we believe that this study give strengths and contribution to HRM literature and practice outweigh its limitations. First, we identified the suitable motivation that should use to explain the effect of employee performance among lecturers - an insight about the role of intrinsic motivation and extrinsic motivation on employee performance in HRM research, specifically in higher learning education. Second, we shed light in identifying the mediating effect of OCB in extrinsic motivation and employee performance -a set of relationship that previous work in this area had left vague and unspecified. Third, we suggested variety of future direction in future research, including longitudinal design to investigate the present study, control the variables that involve investigating the participant self-behaviour or performance. Finally, we are hopeful that future HRM inquiry will acknowledge and attempts to inform the gaps between motivation, $O C B$, employee performance, gender and organizational tenure. 


\section{References}

AROKIASAMY, L.; ISMAIL, M.; AHMAD, A.; OTHMAN, J. (2009). Background of Malaysia private institutions of higher learning and challenges faced by academics. The Journal of International Social Research, 2(8).

BARNARD, C.I. (1938). The Functions of the Executive. Cambridge, MA: Harvard University Press.

BECKER, G. (1964). Human capital: A theoretical and empirical analysis with special reference to education. New York: Columbia University Press.

BEIER, M.E.; ACKERMAN, P.L. (2001). Current-events knowledge in adults: An investigation of age, intelligence, and non-ability determinants. Psychology and Aging, 16: 615-628. http://dx.doi.org/10.1037/0882-7974.16.4.615

BENJAMIN, S.J.; MARATHAMUTHU, M.S.; MUTHAIAYAH, S.; RAMAN, M. (2011). Affordability of private tertiary education: A Malaysian study. International Journal of Social Economics, 38(4): 382-406. http://dx.doi.org/10.1108/03068291111112068

BLAU, P. (1964). Exchange and power in social life. New York: Wiley.

BOERNER, S.; EISENBEISS, S.A.; GRIESSER, D. (2007). Follower behavior and organizational performance: The impact of transformational leaders. Journal of Leadership and Organizational Studies, 13(3): 15-26. http://dx.doi.org/10.1177/10717919070130030201

BOLINO, M.C.; TURNLEY, W.H.; BLOODGOOD, J.M. (2002). Citizenship Behavior and the Creation of Social Capital in Organizations. Academy of Management Review, 27(4): 505-522.

BROOKHART, S.M.; FREEMAN, D.J. (1992). Characteristics of entering teacher candidates. American Educational Research Association, 62(1): 37-60.

CARSTENSEN, L.L.; ISSACOWITZ, D.M.; CHARLES, S.T. (1999).Taking time seriously: A theory of socioemotional selectivity. American Psychologist, 54: 165-181.

http://dx.doi.org/10.1037/0003-066X.54.3.165

CHENG, Y.-C.; YEH, H.-T. (2009). From concepts of motivation to its application in instructional design: Reconsidering motivation from an instructional design perspective. British Journal of Education Technology, 40(4): 597-605. http://dx.doi.org/10.1111/j.1467-8535.2008.00857.x

COHEN, J. (1997). Statistical power analysis for the behavioral sciences (2nd ed.). Hillsdale, NJ: Lawrence Erlbaum Associates Davis and Verma.

COZBY, P.C. (2005). Methods in behavioral research (9th ed.). Boston: McGraw-Hill. 
DECI, E.L.; RYAN, R.M. (1980). The empirical exploration of intrinsic motivational processes. Advances in Experimental Social Psychology, 13: 39-80. http://dx.doi.org/10.1016/S00652601(08)60130-6

DECOENE, V.; BRUGGEMAN, W. (2006). Strategic alignment and middle-level managers' motivation in a balance scorecard setting. International Journal of Operations and Production Management, 26(4): 429-448. http://dx.doi.org/10.1108/01443570610650576

DELUGA, R.J. (1998). Leader member exchange quality and effectiveness ratings: The role of subordinate supervisor conscientiousness similarity. Group and Organization Management, 23: 189-216. http://dx.doi.org/10.1177/1059601198232006

DELUGA, R.J. (1994). Supervisor trust building, leadermember exchange and organizational citizenship behavior. Journal of Occupational and Organizational Psychology, 67: 315-332. http://dx.doi.org/10.1111/j.2044-8325.1994.tb00570.x

EAGLY, A.; CROWLEY, M. (1986). Gender and helping behavior: a meta-analytical review of the social psychological literature. Psychological Bulletin, 100: 282-308.

EHRHART, M.G.; BLIESE, P.D.; THOMAS, J.L. (2006). Unit level organizational citizenship behavior and unit effectiveness: Examining the incremental effects of helping behavior. Human Performance, 19(2): 159-173. http://dx.doi.org/10.1207/s15327043hup1902_4

ERDLE, S.; SANSOM, M.; COLE, M.R.; HEAPY, N. (1992). Sex differences in personality correlates of helping behavior. Personality and Individual Differences, 13: 931-936. http://dx.doi.org/10.1016/0191-8869(92)90010-M

EYAL, O.; ROTH, G. (2011). Principles' leadership and teachers' motivation: Self-Determination theory analysis. Journal of Educational Administration, 49(3): 256-275.

http://dx.doi.org/10.1108/09578231111129055

GEORGE, D.M.; CARROLL, P.; KERSNICK, R.; CALDERON, K. (1998). Gender-related patterns of helping among friends. Psychology of Women Quarterly, 22: 685-704.

http://dx.doi.org/10.1111/j.1471-6402.1998.tb00185.x

GOOD, G.E.; DELL, D.M.; MINTZ, L.B. (1989). Male role and gender role conflict: relations to help seeking in men. Journal of Counseling Psychology, 36: 295-300.

http://dx.doi.org/10.1037/0022-0167.36.3.295

GOULDNER, A.W. (1960). The norm of reciprocity: A preliminary statement. American Sociological Review, 25: 161-178. http://dx.doi.org/10.2307/2092623

HAIR, J.F. JR; ANDERSON, R.E.; TATHAM, R.L.; BLACK, W.C. (2009). Multivariate data analysis (7th ed.). New York: Macmillan Publishing Company. 
HAIR, J.F. JR.; ANDERSON, R.E.; TATHAM, R.L.; BLACK, W.C. (1998). Multivariate Data Analysis (5th ed.). Upper Saddle River, NJ: Prentice Hall.

HERZOG, T. (1996). Research Methods in the Social Sciences. New York: Harper Collins.

ISHAK, M.I.M; SUHAIDA, M.S.; YUZAINEE, M.Y. (2009). Performance measurement indicators for academic staff in Malaysia private higher education institutions: A case study in UNITEN. PMA Conference 2009, University of Otago, Dunedin, New Zealand.

ISLAM, T.; ANWAR, F.; KHAN, S.U.R.; RASLI, A.; UNGKU AHMAD, U.N.; AHMED, I. (2012). Investigating the mediating role of organizational citizenship behavior between organizational learning culture and knowledge sharing. World Applied Sciences Journal, 19(6): 795-799.

KANKANHALLI, A.; TAN, B.C.Y.; KWOK-KEE, W. (2005). Contributing knowledge to electronic knowledge repositories: an empirical investigation. MIS Quarterly, 29 (1): 113-143.

KELSEY, J. (2010). The negative impact of rewards and ineffective praise on student motivation. ESSAI: vol. 8, Article 24. Available at: http://dc.cod.edu/essai/vol8/iss1/24. (Last access date: December, 2012).

KIDDER, D.L.; PARKS, J.M. (2001). The good soldier: who is $\mathrm{s}($ he)?. Journal of Organizational Behavior, 22: 939-959. http://dx.doi.org/10.1002/job.119

MANOLOPOULOS, D. (2008). An evaluation of employee motivation in the extent public sector in Greece. Employee Relationship, 30(1): 63-85. http://dx.doi.org/10.1108/01425450810835428

MANUEL, J.; BRINDLEY, S. (2005). The call to teach: identifying pre-service teachers' motivations, expectations and key experiences during initial teacher education in Australia and the United Kingdom. English in Australia, 144: 38-49.

http://dx.doi.org/10.1080/13664530600587311

MANUEL, J.; HUGHES, J. (2006). 'It has always been my dream': exploring pre-service teachers' motivations for choosing to teach. Teacher Development, 10(1): 5-24. http://dx.doi.org/10.2307/256504

MCENRUE, M.P. (1988). Length of experience and the performance of managers in the establishment phase of their careers. Academy of Management Journal, 31: 175-185.

MEGGINSON, D.; WHITAKER, V. (2003). Continuing professional development. Charted Institutes of Personnel Development, CIPD House, Camp Road, London.

MEYER, J.P.; ALLEN, N.J.; SMITH, C. (1993). Commitment to Organizations and Occupations: Extension and Test of a Three-component Conceptualization. Journal of Applied Psychology, 78: 538-551. http://dx.doi.org/10.1037/0021-9010.78.4.538 
MEYER, M.B.; GRIFFITH, D.A.; DAUGHERTY, P.J. (2004). Maximizing the human capital equation in logistics: Education, experience, and skills. Journal of Business and Logistics, 25: 211-232. http://dx.doi.org/10.1002/j.2158-1592.2004.tb00175.x

MOLM, L.D. (1997). Coercive Power in Social Exchange. New York: Cambridge University Press. http://dx.doi.org/10.1017/СВ09780511570919

MORAN, A.; KILPATRICK, R.; ABBOTT, L.; DALLAT, J.; MCCLUNE, B. (2001). Training to teach: motivation factors and implications for recruitment. Evaluation and Research in Education, 15(1): 17-32. http://dx.doi.org/10.1080/09500790108666980

MORRISON, E.W. (1994). Role definitions and organizational citizenship behavior: The importance of the employee's perspective. Academy of Management Journal, 37: 1543-1567. http://dx.doi.org/10.2307/256798

NG, T.W.H.; FELDMAN, D.C. (2010). Organizational tenure and job performance. Journal of Management, 36(5): 1220-1250. http://dx.doi.org/10.1177/0149206309359809

NIEHOFF, B.P. (2005). A theoretical model of the influence of organizational citizenshipbehaviors on organizational effectiveness. In: D. Turnipseed (Ed.), New Researching Organizational Citizenship Behaviors (pp. 385-397). New York: Nova.

ORGAN, D.W. (1988). Organizational citizenship behavior. The good soldier syndrome. MA: Lexington.

ORGAN, D.W. (1990). The motivational basis of organizational citizenship behavior (Vol. 12). Greenwich, CT: JAI Press.

OSTERLOH, M.; FROST, J.; FREY, B. (2002). The dynamics of motivation in new organizational forms. International Journal of the Economics of Business, 9(1): 61-78. http://dx.doi.org/10.1080/13571510110102976

PODSAKOFF, P.M.; AHEARNE, M.; MACKENZIE, S.B. (1997). Organizational citizenship behavior and the quantity and quality of work group performance. Journal of Applied Psychology, 82(2): 262-270. http://dx.doi.org/10.1037/0021-9010.82.2.262

PODSAKOFF, P.M.; MACKENZIE, S.B.; PAINE, J.B.; BACHRACH, D.G. (2000). Organizational citizenship behaviors: a critical review of the theoretical and empirical literature and suggestions for future research. Journal of Management, 26: 513-563.

http://dx.doi.org/10.1177/014920630002600307

RONESS, D. (2011). Still motivated? The motivation for teaching during the second year in the professional. Teaching and Teacher Education, 21: 628-638.

http://dx.doi.org/10.1016/j.tate.2010.10.016 
ROOK, K.S. (1987). Reciprocity of social exchange and social satisfaction among older women. Journal of Personality and Social Psychology, 52: 145-154. http://dx.doi.org/10.1037/00223514.52.1.145

RYAN, R.M.; DECI, E.L. (2009). Promoting self-determined school engagement: Motivation, learning, and well-being. New York: Routledge.

RYAN, R.M.; DECI, E.L. (2000). Intrinsic and extrinsic motivation: Classic definitions and new directions. Contemporary Educational Psychology, 25: 54-67.

http://dx.doi.org/10.1006/ceps.1999.1020

SCHNEIDER, B.; GOLDSTEIN, H.W.; SMITH, D.B. (1995). The ASA framework: An update. Personnel Psychology, 48: 747-773. http://dx.doi.org/10.1111/j.1744-6570.1995.tb01780.x

SHARMA, S.IL.; DURAND, R.M.; GUR-ARIE, O. (1981). Identification and analysis of moderator variables. Journal of Marketing Research, 18: 291-300. http://dx.doi.org/10.2307/3150970

SICHERMAN, N.; GALOR, O. (1990). A theory of career mobility. Journal of Political Economy, 98: 169-192. http://dx.doi.org/10.1086/261674

SINGER, M.S.; BRUHNS, C. (1991). Relative effect of applicant work experience and academic qualification on selection interview decisions: A study of between-sample generalizability. Journal of Applied Psychology, 76: 550-559. http://dx.doi.org/10.1037/0021-9010.76.4.550

SMITH, C.A.; ORGAN, D.W.; NEAR, J.P. (1983). Organizational citizenship behavior: Its nature and antecedents. Journal of Applied Psychology, 68: 653-663. http://dx.doi.org/10.1037/00219010.68.4.653

STRINGER, C.; DIDHAM, J.; THEIVANANTHAMPILLAI, P. (2011). Motivation, pay satisfaction, and job satisfaction of front-line employees. Qualitative Research in Accounting and Management, 8(2): 161-179. http://dx.doi.org/10.1108/11766091111137564

STROBER, M.H. (1990). Human capital theory: Implications for HR managers. Industrial Relations, 29: 214-239. http://dx.doi.org/10.1111/j.1468-232X.1990.tb00752.x

STURMAN M.C. (2003). Searching for the inverted U-shaped relationship between time and performance: Meta-analyses of the experience performance, tenure performance, and age performance relationships. Journal of Management, 29: 609-640.

http://dx.doi.org/10.1016/S0149-2063(03)00028-X

VALLERAND, R.J. (1997). Toward a hierarchical model of intrinsic and extrinsic motivation. Advances in Experimental Social Psychology, 29: 271-360. http://dx.doi.org/10.1016/S00652601(08)60019-2

VAN DYNE, L.; ANG, S. (1998). Organizational citizenship behavior of contingent workers in Singapore. Academy of Management Journal, 41: 692-703. http://dx.doi.org/10.2307/256965 
WAGNER, J.A.; FERRIS, G.R.; FANDT, P.M.; WAYNE, S.J. (1987). The organizational tenure-job involvement relationship: A job-career experience explanation. Journal of Occupational Behavior, 8: 63-70. http://dx.doi.org/10.1002/job.4030080108

Intangible Capital, 2014 (www.intangiblecapital.org)

Article's contents are provided on a Attribution-Non Commercial 3.0 Creative commons license. Readers are allowed to copy, distribute and communicate article's contents, provided the author's and Intangible Capital's names are included. It must not be used for commercial purposes. To see the complete license contents, please visit http://creativecommons.org/licenses/by-nc/3.0/. 